\title{
Development of Educational Games to Improve the Six Aspects of the Development of Children Aged 5-6 Years
}

\author{
Aristia Dewi ${ }^{1, *}$, Rakimahwati $^{1}$ \\ ${ }^{1}$ Department of Early Childhood Education, Faculty of Education, Universitas Negeri Padang, Padang, Indonesia \\ "Email: aristiadewi01@gmail.com
}

\begin{abstract}
The research aims to develop educational games that can improve the six aspects of the development of children aged 5-6 years. The method used is Research and Development (R \& D) with a 4-D model. The results obtained are educational games that can be used in learning in kindergarten. Based on the results of the Test Validity there are $90 \%$ validity and the practical level reaches $87 \%$ and $94,43 \%$ for children's learning observation, the effectiveness of learning activities trials reaches $95.41 \%$ and the effectiveness of children's learning outcomes is $87.35 \%$. From the results of these tests, this game can be applied and can improve the six aspects of the development of children aged 5-6 years
\end{abstract}

Keywords: educational games, six developmental aspects, 4-D model

\section{INTRODUCTION}

Education is a way of developing potential possessed by humans. Education is a medium for human breeding with the development of capabilities possessed by humans, so that more human glory and human nature are reflected. Education is very important in the process of developing various potentials possessed by humans [1].

The unit of education analysis is human, contains many aspects and its nature is very complex. Because of its complex nature, there is no sufficient limitation. Early Childhood Education is sufficient to explain the meaning of education in full. The limits of education are made by various experts, and the content is different from one another. This difference may be due to its orientation, basic concepts used, aspects that are stressed, or because of the underlying philosophy [2].

Early childhood is the most important part of life in Indonesia, can be seen in terms of adopting the values needed by children. Early childhood is a period of growth and development is very rapid or better known as the golden age or often called the golden age. At this age the child has a period of growth and development where there are developments from various early aspects such as cognitive, social-emotional development, moral religion, language, physical-motoric and psychology. These developments make the learning process for children. Children have a very high curiosity, one of them is curiosity about sex. Children want to know about their own body, know the functions of their organs and also differences with other people's property [3].

This period is the fastest stage in terms of their development, where their personalities are built, they are greatly influenced by their closest environment and are open to all types of learning [4]. The quality of experience gained by children in early childhood will make it more meaningful to reach their future. Naturally children are active learners. They love to observe, explore, imagine, discover, conduct investigations, gather information and share experiences. Learning experiences at an early age can be increased to the higher through caring for parents, teachers for children, so that children can be improved so that positive attitudes toward learning are formed [5].

Learning is a scientific process. Therefore the 2013 curriculum mandates the essence of the scientific approach to learning. The scientific approach is believed to be the golden mark of development and development of students' attitudes, skills and knowledge [6]. Therefore, it is necessary to provide opportunities for children to develop students' attitudes, skills and knowledge to the fullest. For this reason, in foreign institutions, it provides media that support the development of various aspects such as: religious moral values, social emotional, cognitive, motoric, language and art [7].

The learning process to improve children's development is very important, learning activities that need to be programmed, namely in one activity covering six aspects of development [8]. The concept of learning while playing is an activity that can be used to improve six aspects of development in children. In this case, the implementation of early childhood education which covers six fields of development, to prevent the occurrence of developmental inequality, such as children who only develop cognitively, but have problems in social terms [9].

Besides that, the problems that arise due to inequality of development are: children who are only demanded to be cognitively problematic, children who are demanded by their art will have problems with other developments such as cognitive. Therefore the need for learning includes six fields of development in ways that are attractive to children, as stated in the 2013 curriculum, namely, integrated thematic or can also be called thematic learning 
[10]. Creating interesting media is also a dilemma for educators, because they are accustomed to accepting what is available and using makeshift media in institutions, whereas to improve the six aspects of child development, there is a need for media that are attractive to children. Computer-based learning is an interesting thing for children nowadays, in this case educators can use technology as a means of learning for children, such as the presence of educational games, children will be interested, and easy to implement learning processes that emphasize the six aspects of development [11].

\section{RESEARCH METHOD}

Research and development or in English is called Research and Development research methods used to produce certain products and test the effectiveness of these products. According to Brog \& Gall[12] development and education research is a process used to develop educational products as an effective solution or way to overcome problems in learning media. development research has a purpose in its application as stated by [13] explaining that the purpose of implementing development research is to assess changes that occur over a period of time through certain methods and observe a group of subjects for some time. Whereas in the opinion [14] development research aims to produce a product that is considered important and shows the interests that are worthy of being produced and held. The research design used in this study is the research design development of 4D (Four D Models) models according to Thiagarajan[15]. This includes 4 stages, namely defining, designing and developing.

\section{RESEARCH RESULT}

The results of the validation of the educational game for the development of six aspects of child development by the validator, validity analysis using a Likert Scale based on a modified validity sheet from [16]. The results of the educational game validation were carried out on several aspects including content feasibility, linguistic aspects, presentation aspects. In general the results of the validation of teaching materials for the aspect of content eligibility can be on average for each statement between $96.66 \%$ in the valid category, meaning the compatibility of teaching materials with Core Competencies (KI) and Basic Competencies (KD), compact disc learning motion and song include themes, Core Competencies (KI), Basic Competencies (KD), indicators, and lesson objectives.

Validation results from linguistic aspects have an overall validity average of $84 \%$ with valid categories. Thus it can be said that the educational game for the development of six aspects of child development contains the clarity of the information contained in the educational game in accordance with the rules of good and correct Indonesian. The next aspect assessed in the educational game validation stage is the presentation aspect. The validation results in each statement on the presentation aspect have an overall average of $78 \%$ with a valid category. The display design of the educational game is interesting and not monotonous. The conclusion of the analysis of the overall educational game on educational games to improve the six aspects of early childhood development in Kindergarten is valid and ready to be tested.

After the educational game is declared valid, the next step is to conduct a trial to find out the practicality and effectiveness of the educational game developed. The educational game developed can be seen from the observation sheet of the implementation of learning and the results of the teacher response questionnaire analysis. For the results of observations the implementation of learning includes the initial, core and final activities in accordance with the steps of the motion learning and song education game with an average of $94.43 \%$ included in the very practical category. the teacher's response is given to find out the teacher's opinion on the learning tools that have been developed. This response is taken using the teacher response questionnaire instrument. The results of the data obtained from each teacher's questionnaire response to the practicality of the educational game are in the very practical category with a practical percentage of $92.18 \%$. This means that the educational game developed has practicality. Educational games make it easier for teachers to attract children's interest in learning, educational games make it easier for teachers to help children understand learning material.

Product Effectiveness. The educational game developed is seen based on the results of the questionnaire analysis of learning activities and children's learning outcomes, educational games can be said to be effective if they have an effect or a good influence on the achievement of learning objectives. The effectiveness test is carried out after the product is declared valid and practical. The effectiveness of educational games in this study, can be seen from the assessment of the results of the questionnaire analysis of learning activities and children's learning outcomes during the learning process, namely in the form of assessment of activities and learning outcomes of children after using compact disc learning motion and the song produced. For the results of children's learning activities an average of $95.41 \%$ while for children's learning outcomes with learning games of motion and song learning an average of $87.35 \%$. It can be concluded that activities and children's learning outcomes show very effective categories by using educational games.

\section{REFERENCES}

[1] D. Suryana, Pendidikan Anak Usia Dini Teori dan Praktik Pembelajaran. Padang: UNP Press, 2013.

[2] D. Suryana, Pendidikan Anak Usia Dini: Stimulasi \& Aspek Perkembangan Anak. Jakarta: Kencana Predana Media Group, 2016. 
[3] S. I. Safyana, S. Marlina, and Y. Yaswinda, "pengaruh Penggunaan Video Sentuhan Boleh dan Tidak Boleh Terhadap Pendidikan Seks Anak," JFACE J. Fam. Adult, Early Child. Educ., vol. 1, no. 1, pp. 64-71, 2019.

[4] L. Latiana, Samsudi, Sugiyo, and Slameto, "The Journal of Educational Development Developing Collaboration-Based Supervision Model to Enhance the Professionalism of Early Childhood Education Teachers," J. Educ. Dev., vol. 6, no. 1, pp. 132-143, 2018.

[5] D. Eliza, "Penerapan Model Pembelajaran Konstektual Learning (CTL) Berbasis Central di Taman Kanak-kanak," Pedagog. | J. Ilm. Ilmu Pendidik., vol. XIII, no. 2, pp. 93-106, 2013.

[6] D. Suryana, "Pembelajaran Tematik Terpadu Berbasis Pendekatan Saintifik di Taman Kanak-kanak," $J$. Pendidik. USIA DINI, vol. 11, no. 1, pp. 67-82, 2017.

[7] Suyadi, Teori Pembelajaran Anak Usia Dini. Bandung: PT. Remaja Rosdakarya, 2014.

[8] C. Kiewra and E. Veselack, "Playing with Nature : Supporting Preschoolers ' Creativity in Natural Outdoor Classrooms," Int. J. Early Child. Environ. Educ., vol. 4, no. 1, pp. 71-96, 2016.

[9] C. Mischo and J. Strohmer, "The Development of Early Childhood Teachers' Language Knowledge in Different Educational Tracks," J. Educ. Train. Stud., vol. 3, no. 2, pp. 126-135, 2015.

[10] A. Prastowo, "Pemenuhan Kebutuhan Psikologi Peserta Didik SD/MI melalui Pembelajaran Tematik terpadu," JPSD J. Pendidik. Sekol. Dasar, vol. 1, no. 1, pp. 1-13, 2014.

[11] Risqi Rahman, "Hubungan antara Self-Concept terhadap mMatematika dengan Kemampuan Berpikir Kreatif Matematik Siswa," Infinity, vol. 1, no. 1, pp. 1930, 2012.

[12] Sugiyono, Metode Penelitian Pendidikan: Pendekatan Kuantitatif, Kualitatif dan R\&D. Bandung: Alfabeta, 2014.

[13] P. Setyosari, Metode Penelitian Pendidikan dan Pengembangan. Jakarta: Kencana, 2016.

[14] Sugiyono, Metode penelitian pendidikan:(pendekatan kuantitatif, kualitatif dan $R \& D)$. Bandung: Alfabeta, 2008.

[15] Trianto, Mendesain Model Pembelajaran Inovatif-Progresif. Jakarta: Kencana Predana Media Group, 2009.

[16] Riduwan, Belajar Mudah Penelitian untuk GuruKaryawan dan Peneliti Pemula. Bandung: Alfabeta, 2009. 